\title{
Corruption in Russia: concept, types, determinants
}

\begin{abstract}
Today, corruption is not only a problem of Russia, it is a problem of many countries. Corruption destroys the moral fabric of society and poses a serious threat to the security of society. At the same time, there is no single and unambiguous concept of this phenomenon in science. Based on the analysis of different approaches to the definition of the term "corruption", the concept of corruption is clarified. The author identifies the types of corruption crimes, forms of corruption, the most common in Russia, and analyzes the consequences of corruption crimes. The main causes and conditions that contribute to the reproduction of corruption in Russia are identified. In conclusion, the author comes to the conclusion that the understanding of the determinants will help to improve the focus of the authorities and the office for the prevention of corruption crime.
\end{abstract}

Volume 7 Issue 4 - 2019

\author{
Vladimir G Gromov \\ Environmental Law and Criminology, Saratov National Research \\ State University, Russian
}

Correspondence: Vladimir G Gromov, Doctor in Law, Professor, Chair of the Criminal, Environmental Law and Criminology, Saratov National Research State University, Saratov, the Russian Federation, Email gromov_vg@mail.ru

Received: July 13, 2019 | Published: July 18, 2019

Keywords: corruption, corruption crimes, forms of corruption, causes of corruption, prevention of corruption

\section{Review}

The problems of corruption have been the subject of scientific research for a long time, both in Russia and abroad, but the issues of anti-corruption policy have been investigated not widely enough. Therefore, every year the interest of scientists in this topic only increases. The fact that corruption in Russia is a large-scale problem is evidenced by the data of the corruption rating of officials - Russia is among the top ten most disadvantaged countries in the world. ${ }^{1}$ This is explained, firstly, by the fact that corruption permeates all spheres of society's life, where previously it was not expected to be found. Secondly, by the fact that, despite the establishment of relative political stability and the formation of a democratic civil society, the problems of corruption are gaining spreading; One can agree with $\mathrm{Yu}$ G. Babayeva that the most important reason for formulating the legal definition of corruption is that the concept of corruption goes beyond the boundaries of criminology and law research and is a complex synthetic socio-philosophical and criminological concept. ${ }^{2}$ In art. 15 of the UN Convention against Corruption, approved by the UN General Assembly Resolution A/RES/3514 (XXX) adopted December 15,1975 , corruption is defined as intentional criminal offenses, not including civil delicts, disciplinary and administrative offenses; by forms of manifestation is limited to active and passive bribery; the bribery of the officials themselves or categories of persons, equivalent to them, providing public services. It is worth noting that international legal acts in the field of corruption counteracting do not provide an accurate and unambiguous understanding of this phenomenon, defining corruption by listing acts attributable to corruption.

For example, the Criminal Law Convention on Corruption of the Council of Europe, adopted 27 January 1999, refers to corruption such things as passive and active bribery of: national officials; members of foreign and national assembly's; foreign officials; officials of international organizations; members of parliamentary international meetings; judges and officials of international courts; national and foreign arbitrators; national and foreign jurors; bribery in the private sector; the use of official position for self-enrichment; laundering of income from crimes related to corruption; crimes related to operations with bank accounts. ${ }^{3}$ It can be argued, that corruption has long been not a problem of any single state, but has a transnational nature, which is alarming both in the Russian Federation and on the scale of the entire international community. At present, science does not have a unified opinion on the concept of "corruption". Very interesting, and more relevant to reality in our opinion, is the definition of corruption proposed by Professor V.V. Luneev. In his understanding, "corruption is a phenomenon more widespread than bribery. It covers any abuse by officials committed with selfish goal. Lobbyism, favoritism, protectionism, contributions for political purposes, investment of commercial structures at the expense of the state budget, transfer of state property to joint-stock companies, use of criminal communities, etc. are veiled forms of corruption" ${ }^{4}$ In turn, the essence of corruption lies in anti-state mercenary behavior, in "abuse of official or social status in selfish interests" in "the use of the rights and power entrusted to officials for the purpose of personal enrichment" "is spread not only in the system of power, but also in the private sector". ${ }^{7}$ It should be noted that the content of corruption relations determines the forms of corruption manifestations - corruption misdemeanours and crimes.

However, despite the fact that Russian legislation still has no define concept of a corruption crime, this has not prevented the legislator from identifying its main types. Thus, at present Russian legislation defines the following types of corruption:

i. Receiving and giving bribes - the most dangerous and the most common form of corruption crimes with high level of latency;

ii. Commercial bribery;

iii. Concealment, misappropriation, retention or other misuse of funds or property if the considered person is aware that these funds or property have been obtained illegally;

iv. Fraud - unlawful mercenary behavior through the intentional criminal manipulation of information with use of the official position: deception, the provision of knowingly false or incomplete information, abuse of confidence, concealment of circumstances;

v. Official forgery - distortion of truth in selfish interests, inserting into official documents of knowingly false information that distorts the meaning of the document, making a fictitious (counterfeit) document, changing the content of the original document. 
However, there are other specific forms of corruption, such as favoritism, nepotism and protectionism. The legislative definition of these concepts is reflected in separate codes of professional ethics for various civil servants. For example, art. 23 of the "Code of Professional Ethics of the employees of the internal affairs authorities" establishes that protectionism is thought of as a system of patronage, career promotion, the granting of advantages due to kinship, common region of origin, personal loyalty, and friendly relations for the purpose of gaining selfish gain. Nepotism and favoritism are described as demonstrative proximity of favourites and general patronage in the service. $^{8}$ The peculiarity of all the forms of corruption considered is that they are not standing still, but are in constant development, and therefore lawbreakers are using ever more sophisticated forms of corruption. Based on the foregoing, it follows that any form of corruption manifestation is always inherently a violation of ethical and legal norms by persons authorized to perform public functions. The global network of companies "PwC", having conducted a survey of 120 different companies, believes that the most common types of corruption crimes in Russia are the following:

a. misappropriation of assets - $72 \%$;

b. fraud in the procurement of goods and services - 33\%;

c. Bribery $-30 \%{ }^{9}$

Speaking about the causes of corruption or the so-called determinants, it should be noted that it is impossible to single out any as the main one. We believe that the causes of corruption should be thought of as a single set of interrelated causes, due to a number of economic, social, cultural and legal factors. Thus, for example, today we can observe the imbalance of the branches of power in the political sphere. At present, the executive branch is in full control of the situation in the country. It, having a majority in the parliament, easily conducts its legislative policy. The state is managed in a "manual mode". The unsystematic decisions are being taken to achieve a momentary positive response. At the same time, this imbalance is contrary to the principles of democracy. Officials and loyal authorities believe in their infallibility and continue to grow rich at the expense of taxpayers. As to economic and social factors, they are caused by the economic crisis, high rates of unemployment, low salaries, rising prices, stratification of the population into rich and poor. The amount of Russians, whose income is below the living wage, is 20 million people,${ }^{10}$ and in the past 2 years the number of Russians living below the poverty line has increased by three million people, with $60-70 \%$ of these poor are being families with children. A decrease in the standard of living was noted by $50 \%$ of the inhabitants of the country. ${ }^{11}$ Unsatisfactory state support of the population pushes citizens to receive other, illegal proceeds, often through corruption. The cultural determinants of corruption in Russia, according to some scholars, are present due to the mentality and history of nation. Other scientists argue that one of the most important causes of corruption is a low legal consciousness and a low legal culture. We share this view and believe that the fight against corruption must begin in the minds of those who are accustomed to solving their problems through shortcuts. And this is the task of forming an anti-corruption sense of justice in society, which must be formed in every person from early childhood.

In this regard, as it seems to us, it is necessary to conduct activities for the whole society and individual social groups regarding the dangers of corruption, as well as its impact on the development of our country. This can be done through the introduction of compulsory legal education and education of citizens, the introduction of relevant disciplines in general education and higher education. Thus, each person should form a "spiritual and moral taboo" on the possibility of participating in corrupt schemes. The legal factors of corruption include gaps and conflicts in law, by which offenders "bypass the law" or present serious corruption crimes as crimes against property, which have less public danger. The main tool for overcoming conflicts and gaps in normative and legal acts of the executive branch, laws adopted by the State Duma or legislative assemblies of the subjects of the Russian Federation and their projects is anti-corruption expertise based on the creation of a list and description of typical corruption-related factors associated with the use of the powers of state authorities and local self-government. ${ }^{12}$ However, the above reasons are interdependent, and when counteracting corruption they must be taken into account systemically. Speaking about the consequences of corruption, it is worth noting that it is the real damage caused by corruption to state and public interests. In the field of economic relations, the consequences of corruption are expressed in the slowdown of economic development, which contributes to the elimination of free economic competition, the establishment of monopoly, and the deterioration of the investment climate in the country.

In addition, corruption contributes to higher prices for goods and services, and significantly stimulates the growth of the shadow economy. In political relations, the main consequence of corruption is the weakening of the state due to its seizure, factual privatization by private oligarchic structures. In addition, corrupt practices undermine citizens' trust in government structures, reducing their authority among the population of the country. Accordingly, it creates an unwanted image of the state and its leadership in the international arena. With regard to the social sphere, corruption increases tensions in society, and also contributes to the growth of social injustice. Along with this, corruption also undermines public security, as due to its repetitive nature, many crimes are out of sight of law enforcement agencies, society and the state, among them - crimes of a terrorist nature and crimes of an international character. In the spiritual and ideological sphere, tolerance for corruption is increasing, which is increasingly perceived by public opinion as a "norm of life." Accordingly, when citizens observe corruption behavior of officials or witness an illegal decision, the legal nihilism is growing among them. In 2015, the National Security Strategy was adopted.

According to paragraph 43 of the Strategy, to date corruption, along with terrorism and extremist activity, is one of the main sources of "threats to national security in the sphere of state and public security"13 which in turn confirms the position of V.V. Putin on the importance of counteracting corruption. Speaking about anti-corruption policy, it is worth noting that it consists of development and implementation of various and consistent measures by the state and society to eliminate (minimize) the causes and conditions that generate and nourish corruption in various spheres of life. However, in our opinion, the formation and development of anti-corruption policy is not a goal in itself. This should result in reduction of the negative impact of corruption on society, and the assistance in the creation of an honest and effective system of government at all levels of government. Due to the fact that one of the causes of corruption is "vulnerability" of authorities, a huge influence within the anti-corruption policy of the state should be provided by the "Code of Ethics and Official Behavior of Civil Servants of the Russian Federation and municipal 
employees", approved by the Presidium of the Presidential Council for Countering Corruption of December 23, 2010. ${ }^{14}$

The Code is presented in the form of a set of general principles of professional ethics; its main goal is to establish ethical norms and rules of official conduct of civil servants, to strengthen of the authority of the state and municipal employees and to raise the citizens' confidence in state agencies. In our opinion, this normative act is aimed at increasing the efficiency of the performance of their official duties by public servants. In addition, the "Code of Ethics and Official Conduct of Civil Servants of the Russian Federation and municipal employees" provides for the responsibility of public servants. It should be noted that at present only the foundations of a national anti-corruption policy are laid in Russian Federation, the policy itself still has to be formed. In forming the state anti-corruption policy, along with the general social, the role of legal measures is also important. Legal measures to counteract corruption must include a wide range of laws, not only industry-specific, but also complex, which bring together a multitude of legal means of influencing corruption systematically. Moreover, since the corruption counteraction involves the use of a system of economic, political, legal, psychological, instructional and educational measures, the legislation acts only as one of the tools for counteracting corruption.

We believe that attention should be paid also to other tools for countering corruption, for example:

i. Strict observance of human rights and citizenship;

ii. Increase of the level of legal culture and legal consciousness of society;

iii. The development of local government;

iv. free media;

v. an independent judicature;

vi. Development of civil society, as well as ethical standards, both for business and for society as a whole.

The corruption counteraction in Russia should solve one more problem - the task of forming an anti-corruption sense of justice in society, which should be instilled to every person from early childhood. Regarding this, it is necessary to carry out activities for the whole society and individual social groups about the damage done by corruption, as well as its negative impact on the development of our country. This can be done through the introduction of compulsory legal education of citizens, the introduction of relevant disciplines in general education and higher education. Thus, each person should form a "spiritual and moral taboo" to participate in corruption schemes. In Russian Federation, the state formed the basis for anticorruption policy, but in addition to setting the foundation for the corruption counteraction, there must be a desire of people to confront this terrible vice of modern society. The effective interaction between state and society will be possible only when the state will inspire confidence among its citizens. Only then will it be possible to reduce the indicators of corruption in all spheres of society's life.

\section{Acknowledgments}

None.

\section{Conflicts of interest}

The author declares that there are no conflicts of interest.

\section{References}

1. Shediy MV. Corruption in modern Russia: the problems of counteraction. "Izvestiya" of Tula State University. Humanitarian sciences. 2011;2:242-251.

2. Babaeva Yu G. On the question of the legitimization of the concept of "corruption" Rights and freedoms of man and citizen: theoretical aspects and legal practice. Materials of the annual International Scientific Conference. 2015;272-274.

3. The Criminal Law Convention on Corruption of the Council of Europe (Strasbourg, 27.01.1999). Collection of Legislation of the Russian Federation. 200920. Art. 2394.

4. Luneev VV. Crime of the XX century: world, regional and Russian trends, Ed. 2nd, Rev. and extra. 2005;267 p.

5. Anti-corruption strategies for countries with transitional economy. In: Sikora I, editor. 2002;9 p.

6. The legal encyclopaedia. In: Tikhomirova M Yu, editor. Moscow: Yurinformtsentr. 2005;443 p.

7. Rumyantseva EE. Anti--corruption mechanisms. Monograph. Moscow: GOUVPO VGNA of the Ministry of Finance of Russia. 2012;16 p.

8. On the approval of the Code of Professional Ethics of an employee of the internal affairs of the Russian Federation. Order No. 1138 of the Ministry of Internal Affairs of the Russian Federation. 2008.

9. Russian survey of economic crimes. 2016.

10. Message of the President of the Russian Federation VV. Putin to the Federal Assembly of the Russian Federation. Krimlin. 2018.

11. The Economist: "The income of Russians is spent not even for food, but for elementary survival".

12. On anti-corruption examination of normative legal acts and drafts of normative legal acts: Resolution of the Government of the Russian Federation No. 96 of February 26, 2010. Collected Legislation of the Russian Federation. 2010;10(2058).

13. On the National Security Strategy of the Russian Federation: Decree of the President of the Russian Federation of December 31, 2015 No. 683. Collection of Legislation of the Russian Federation. 2016;1(part 2). Art. 212.

14. The Code of Ethics and Official Conduct of Civil Servants of the Russian Federation and Municipal Employees. Ministry of labour Russia. $2011 ; 36$. 